\title{
Critical Discourse Analysis on Students' Comments on Tate Confessions
}

\author{
Pastolero, Nelson P* \\ Philippines \\ *Corresponding Authors: Pastolero, Nelson P, Philippines
}

\section{INTRODUCTION}

The study entitled Critical Discourse Analysis on Students' Comments on Tate Confessions aimed to determine the common lexical features, syntactic features, language functions, and ideologies of students' comments on Tate Confessions.

The study made use of the descriptive-qualitative method as the researcher collected, classified, analyzed, and then interpreted the data from comments of Davao Oriental State College of Science and Technology' students found in Tate Confessions using critical discourse analysis.

The results revealed that the common lexical features found on the comments of students include onomatopoeia which ranked first with a frequency of 80 . This is followed by loan words with 55 occurrences; abbreviations, 42; acronyms, 23; reduplication, 16; repetition, six (6); swear words, four (4); taboo words and expressions, two (2); and blends with one (1) occurrence.

In terms of the syntactic features used in the comments of students, the study found out four sentence classes such as declarative with 111 occurrences; imperative with 42; exclamative with 40; and interrogative with 34 .

The language functions found include ideational with 56 in frequency (composed of expressions on wisdom, humour, resentment, patriotism, human rights, proverbs and descriptions); interpersonal with a frequency of 51 (expressing personal feelings, insult, faith, sex, and challenge); and textual, having a frequency of 10 (expressing glorification, movie title, and political content).

The common lexical features that determined ideologies of students in Tate Confessions include: taboo (sex), loan words (education, self identity), swear words (discrimination on state of mind), repetition (discrimination on ability), reduplication (discrimination on ability), acronyms (education), and abbreviations (on self identity).

The common syntactic features that determined ideologies found on students comments are the following: declarative (discrimination based on education, stereotyping, power, sex, self and group identity, life, and love), interrogative (discrimination based on education, physical appearance, power) imperative (discrimination based on education, stereotyping, faith, power, sex, life, environment), and exclamative (discrimination based on education, physical appearance, faith, life, love, advice or warning, power).

Based on the findings of the study, it is recommended that since the comments of the students contain ideologies, English and language teachers should remind students who post comments on Facebook to be clear on the message that they are posting by writing correct spelling, punctuations, and sentence crafts to avoid misunderstanding and confusion that would lead to a more heated arguments. On the other hand, teachers should not dominate students nor manipulate them since it would only affect the students' both emotionally and academically. Teachers and students should discuss issues on grades, even on sex and love whenever necessary in a positive perspective to avoid conflict and discrimination. The administration should likewise support endeavours like seminars enhancing English faculty on their strategies and methods in teaching English and language to remedy problems in English language learning and use.

The study could be a basis for the guidance and counselling office to intervene problems in behavior of students who are particularly offensive and rude, and oftentimes more sarcastic than being careful 
on their expressions shared on social networking sites. Future research especially on ideologies are recommended to investigate the trends in modern age and in the digital world, particularly with the use of social networking sites where new groups emerged, in which the CDA frameworks of van Dijk (1998) could be best applied.

\subsection{Rationale}

All human beings normally speak at least one language, and it is hard to imagine much significant social, intellectual, or artistic activity taking place in its absence (O'Grady and Katamba, 1996). A language can function in many ways, such as to find or give information, manipulate or give orders (McCroskey, 2007). A language user uses these different functions in different situations and contexts. Language also gives structure to experience, and helps one to determine the way of looking at things, so it requires some intellectual effort to see them in any other way that which the language suggests (Lyons, 1970). In addition, language marks one's identity, physically, in terms of sex, and voiceprints; psychologically in terms of language and personality, intelligence; geographically stratification, class, status, role, solidarity and distance (Crystal, 1992).

According to van Dijk (1998), if language users explicitly or unwittingly express their ideologies through language communication, these could be uncovered by close reading, understanding or systematic analysis. Van Dijk (1998) later developed CDA or critical discourse analysis, the framework which would be the basis for analyzing language functions and ideologies. CDA sees language as socially shaped, and is likewise socially shaping or constitutive. The overall notion of the framework is based on the crucial notions of discourse, cognition and society, where discourse is primarily text based (syntax, lexicon, local semantics, topics, schematic structures, etc.).

On the other hand, Wodak and Meyer (2008) believed that the use of language is a social practice which is both determined by social structure and contributes to stabilizing and changing that structure simultaneously. With the emergence of new 'societies' like the social networking sites, this argument is likewise believed to be significant for further study. On the surface, Facebook as a social networking site, provides an invaluable resource for fulfilling such needs by allowing people to instantly connect.

Crystal (2001) said that language is the heart of the internet. He reasons that language is central to the revolution and explores the role of language in the Internet and the effect of the Internet on language. He concludes that Netspeak (language of the Internet) is a new medium, "neither spoken language nor written language nor sign language, but a new language dimension computer-mediated language." Crystal sees Netspeak creating huge opportunities for the expansion and enrichment of language.

In Davao Oriental State College of Science and Technology, Facebook comments of students were seen significant for study. The researcher as a language and English mentor found it interesting to put into analysis these comments since these have affected not only students' ideologies and their academic performances.

The researcher found it reasonable to investigate the underlying language functions that he inconspicuously observed while checking his own Facebook account. Further, these comments were seen significant since the communicated ideas, feelings, and emotions are ideological.

It is in this reason that this study was pursued. Utilizing Critical Discourse Analysis (CDA) as a method helped the researcher find out the existing linguistic phenomena in morphology and syntax, language use and ideologies present on DOSCST students' Facebook comments in the group or forum Tate Confessions.

\subsection{Statement of the Problem}

Generally, the study examined the Facebook comments of students in Davao Oriental State College of Science and Technology and how these students used language to express their ideologies.

Specifically, the study would answer the following questions:

1. What are the lexical features of the Facebook comments of the students?

2. What are the syntactic features of the Facebook comments of the students?

3. What are the language functions in the Facebook comments of the students?

International Journal on Studies in English Language and Literature (IJSELL) 
4. What are the lexical and syntactic features which determined the ideologies of the students?

5. What are the ideologies found in the Facebook comments of the students

\section{MeTHODS}

\subsection{Research Design}

This study made use of qualitative research where Atkinson et al. (1998) outlined seven different approaches used in British educational research deriving from symbolic interactionism, anthropology, sociolinguistics, ethnomethodology, qualitative evaluation, neo-Marxist ethnography, and feminism.

This research focused in sociolinguistics utilizing social networking site Facebook where natural setting, interests in meaning, assumptions influencing behavior, perspectives and understanding with the emphasis on process were given value. This study employed Critical Discourse Analysis (CDA) to describe and analyze the Facebook comments of DOSCST students based on lexical and syntactic features, language functions and ideologies stated or implied in the data gathered.

\subsection{Corpora of the Study}

Only comments of students from Davao Oriental State College of Science and Technology posted on Tate Confessions were utilized as data which were analyzed using Critical Discourse Analysis. The period of coverage for students' comments was from March 1-31, 2014, taking into consideration the post comments and photo comments.

\subsection{Research Procedures}

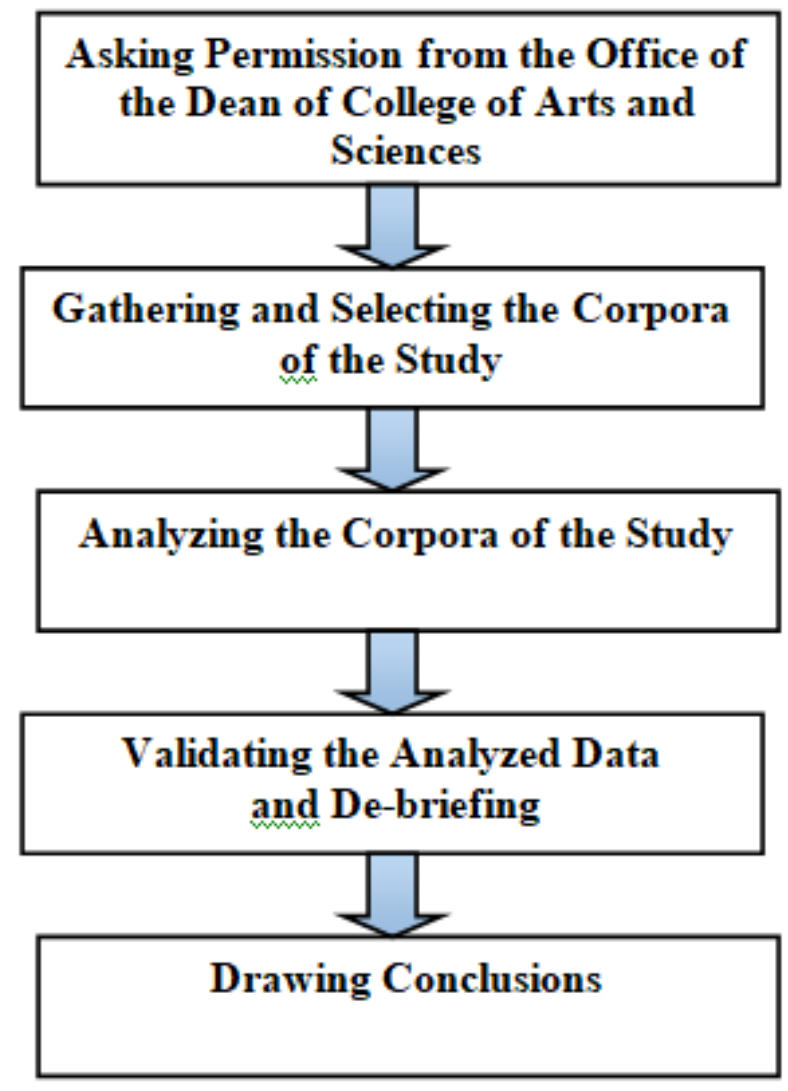

Fig1. Flow chart of the procedures observed in the study

The following steps were observed in the conduct of this study:

\subsection{Asking Permission}

The researcher sought the approval of the Dean of the College of Arts and Sciences and the President of the DOSCST to allow him to conduct this study. 


\subsection{Retrieving Data}

The following procedures were followed by the researcher to obtain the data relevant to draw the conclusions for the study.

a) The data were collected from Facebook posts by copying the whole page and extracting the comments of students from various topics. Information Technology expert friends and colleagues assisted the researcher in copying and printing the comments for analysis.

b) The empirical and note taking methods were used to explicitly arrive at a credible data since the students were not informed to be part of the study to avoid bias and apprehensions on their part as "commenters".

\subsection{Data Analysis}

Critical Discourse Analysis by Van Dijk (1998) was utilized to analyze the data gathered. According to Van Dijk (1998), ideology may in principle show up anywhere in discourse, yet, ideological "content" is most directly expressed in discourse meaning.

In assessing ideologies found in students Facebook comments, the analysis started on semantic monostructures of the text, that is, with the study of global meanings, topics or themes. Such topics represent gist or most important information of a discourse, and tell what a discourse 'is about', globally speaking.

Then the researcher focused on meaning, such as meaning of words (lexical), structure and nature of propositions, and coherence and other relations between propositions, such as implications, presuppositions, level of description or degree of detail, contrast, examples and illustrations, disclaimers, actors, modality, evidentiality, hedging and vagueness, and topoi.

In this study, ideological analysis was limited to semantics since it may affect the various formal structures of text and text itself such as the form of a clause or sentence, the form of an argument, the order of a news story, the size of a headline, and so on. This means the study of syntax, argumentation, and so on.

Then, the researcher analyzed the ideologies which were focused on language functions. Analyzing discourses involves looking at both language form and language function (Demo, 2001). According to Keraf (1996), language has some features that are used based on human needs as a tool to express one self, to communicate, to organize and to adapt into social integration in the environment, and to do social control. The purpose for which speech or writing is being used in called language function. Language functions, therefore, refer to the purposes in which one uses language to communicate.

Lastly, the ideological content of students Facebook comments in DOSCST required not only examining meaning and form but also in social dimension-action and interaction. Discourses when uttered in specific situation may accomplish the speech act of an assertion, a question, an accusation, a promise or threat.

\subsection{Peer-review Debriefing}

The data gathered, tabulated, and analyzed using Critcal Discourse Analysis as a method by Van Dijk served as bases of the conclusions and recommendations of this study. The results were validated with the help of the thesis adviser Prof. Rowena C. Nuera. Also, the assistance of Mr. Sajed S. Ingilan, a language instructor of the language department, CAS-USeP was sought as per recommendation by the panel of reviewers to further make the data free of biases or subject

\section{ReSUlts AND Discussions}

\subsection{Lexical Features of Students' Facebook}

\section{Comments on Tate Confessions}

Onomatopoeia is the naming of a thing or action by a vocal imitation of the sound associated with it; or it is the use of words whose sound suggests the sense. 


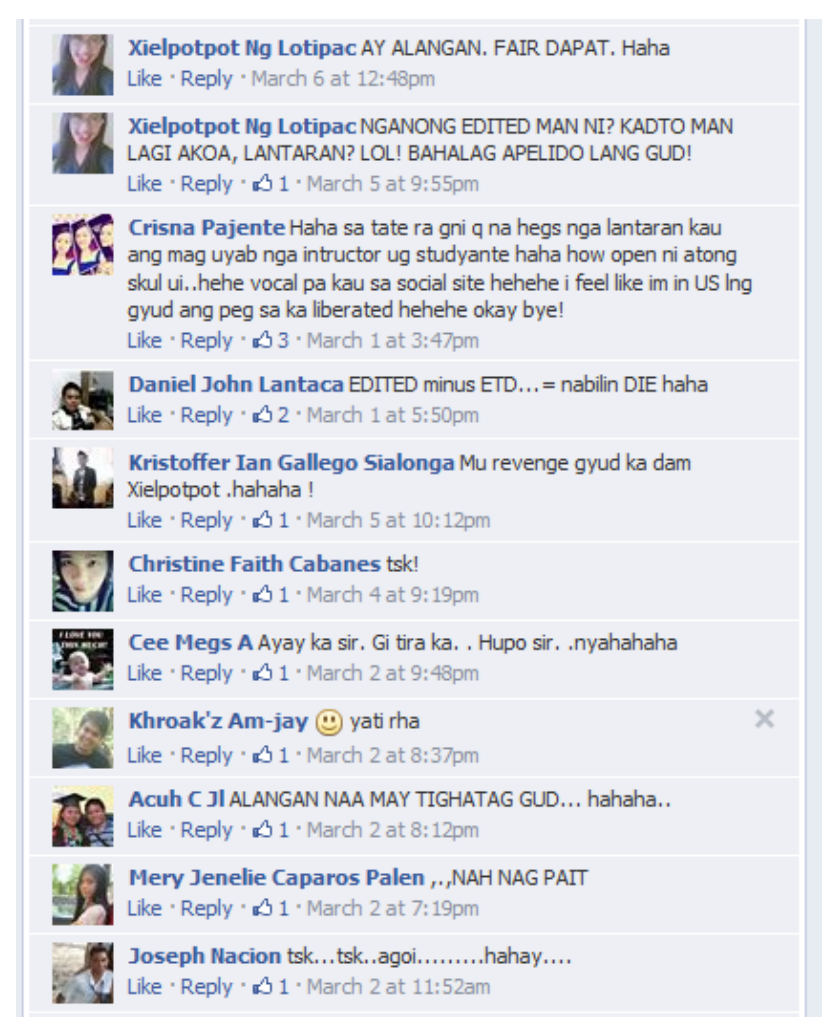

The examples "tsk, hahaha, nyahahaha, agoi, hahay, hehe, tsk, hahay, aahh, ayyy, awww, ehh, hihi, tss, hmm, boom, toinks are some of the lexical features that suggest word properties of onomatopoeia.

In the context "Ayay ka Sir. Gi tira ka. Hupo Sir, nyahahaha", the commenter specifically addresses a straightforward remark to a faculty who is involved in a confession regarding a scandalous teacherstudent indecent relationship. It is assumed that the student has directly assaulted the faculty with a satirical statement punctuated by an onomatopoeic word 'nyahahaha' which clearly ridicules from an advised message 'hupo sir'.

On the other hand, another commenter just posted a very short message yet may sound very interesting for readers. "Tsk", is an expression of sigh, disgust, or maybe disappointment on her part. This word resembles a sound 'we' normally utter when things go wrong or the expected outcomes fall short.

In addition, these lexical items exhibit extraordinary features particularly in orthography since these are patterned from the existing sounds and are transcribed based on the commenter's basic knowledge of English phonology, though the words written on a conversation are basically of Cebuano in phonetic properties, that is they are heard, if uttered in native language's accent.

Loan words refer to foreign or borrowed words taken from another language. According to Espinosa (1997), English, in some areas of the Philippines is more popular than Filipino. She further stated that the fact that the Philippine education system has been using English as medium of instruction from elementary to university level for decades has also reinforced the notion that English is easy and available.

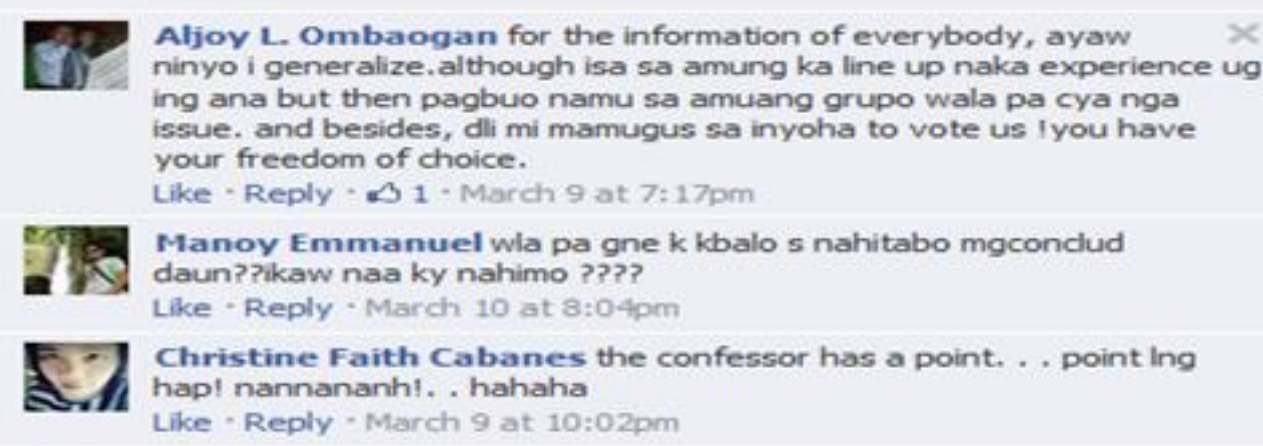


Affixes are bound morphemes which have one or more identifiable semantic or grammatical functions/meanings and which occur in more than one word in the language (McIntyre, 2010).

In the above post, the example 'mag' (mag-conlude) as a Cebuano prefix is assigned to tense signifying the future action. Same is true with ' $i$ ' (i-generalize) a prefix that ideally determines the future tense of verb when attached with English verb.

On the other hand, this phenomenon is reversed for 'naka' when attached to English verbs. The example "naka-exeprience" clearly demonstrates a completed aspect of the action taken.

Also, the prefix ' $\mathrm{ka}$ ' when attached to English nouns doesn't affect any aspect of the English word. This is observed in the context "ka-line up", where there is no significant change in the properties of the English noun 'line-up'. Unlike in 'mag', ' $i$ ' and 'naka', these Cebuano prefixes could be safely considered as tense markers when attached to English verbs. Both prefixes "mag" in "mag'conclude" and " $i$ " in "i-generalize" indicate future actions, while prefix "naka" in "naka-experience" instanatiated past action.

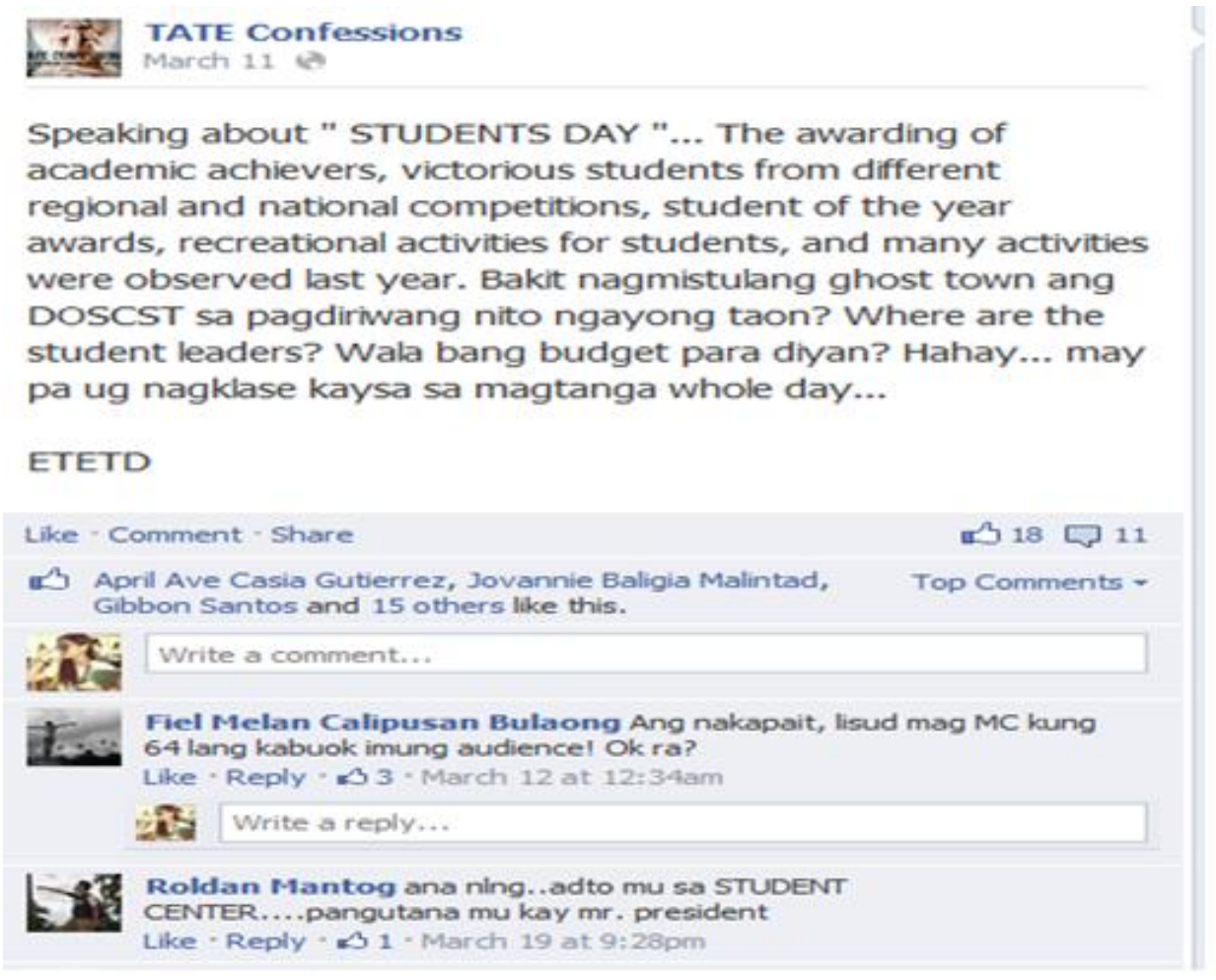

\begin{abstract}
Abbreviations are the contracted forms of words or phrases. It has been observed that the common trick of abbreviating words in comments found on Tate Confessions is similar to that of text language, or textspeak.
\end{abstract}

The wiktionary.org (2013) cited in Barbosa (2013) defined textspeak as any of a number of different measures of abbreviation to shorten length of text messages, such as eliding vowels, foregoing the use of punctuations representing "you" and "your" as "u" and "ur", using "da"(or rarely "d") in place of "the", and so on. This is evident in the way comments were written, thus implying that text language has a great influence in the writing styles of students in the college.

The example "Ok" is a universal abbreviated word for 'okay'. "MC", on the other hand, is a version for the whole words in master(s) of ceremony.

The screen shot post reveals that students conveniently use their creativity in posting comments, not only that they abbreviate words but also include punctuations to emphasize their points.

Other examples found in the study also include Tate (State College), ya (kuya, elder brother or elder man), ok (okay), wen (when), docs (document), u (you), brayt (bright), and INC (incomplete).

Students have to use abbreviations to save both time and effort since using these words lessen number of characters and eventually would save time. Presumably, these abbreviations are well-understood by students since they are using them not only in Facebook comments but in sending messages alike. 
Acronym is a word formed from initial letters of a name, or by combining initial letters or parts or series of words. It is a word formed from the initial letter or letters of each of the successive parts or major parts of a compound term.

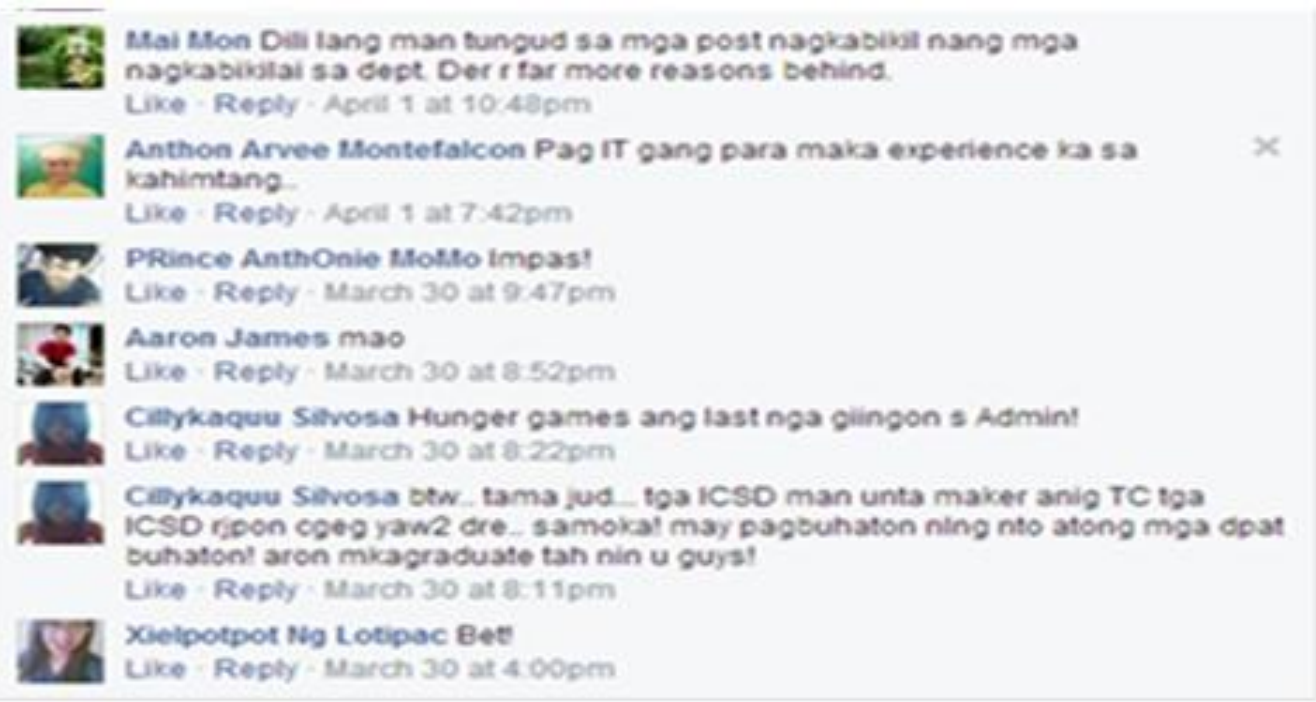

Acronyms above like IT (Information Technology) and ICSD (Information and Computer Science Department) are found among the lexicon of students in Tate Confessions.

In the context 'tga ICSD man unta maker aning TC tga ICSD rjpon cge yaw2 dre.' gives a clear picture of abbreviations. Both are used to shorten the entire equivalent of the abbreviated entities which very long and time consuming for a commenter to encode, and perhaps for the reads to read.

Reduplication is also one of the commonly used lexical features found in the students' Facebook comments on Tate Confessions. Students particularly write in reduplication forms to emphasize an expression especially if no English counterpart is possible. Katamba et al. (1996) states that reduplication is a morphological process which duplicates all or part of the base to which it applies to mark grammatical or semantic contrast.

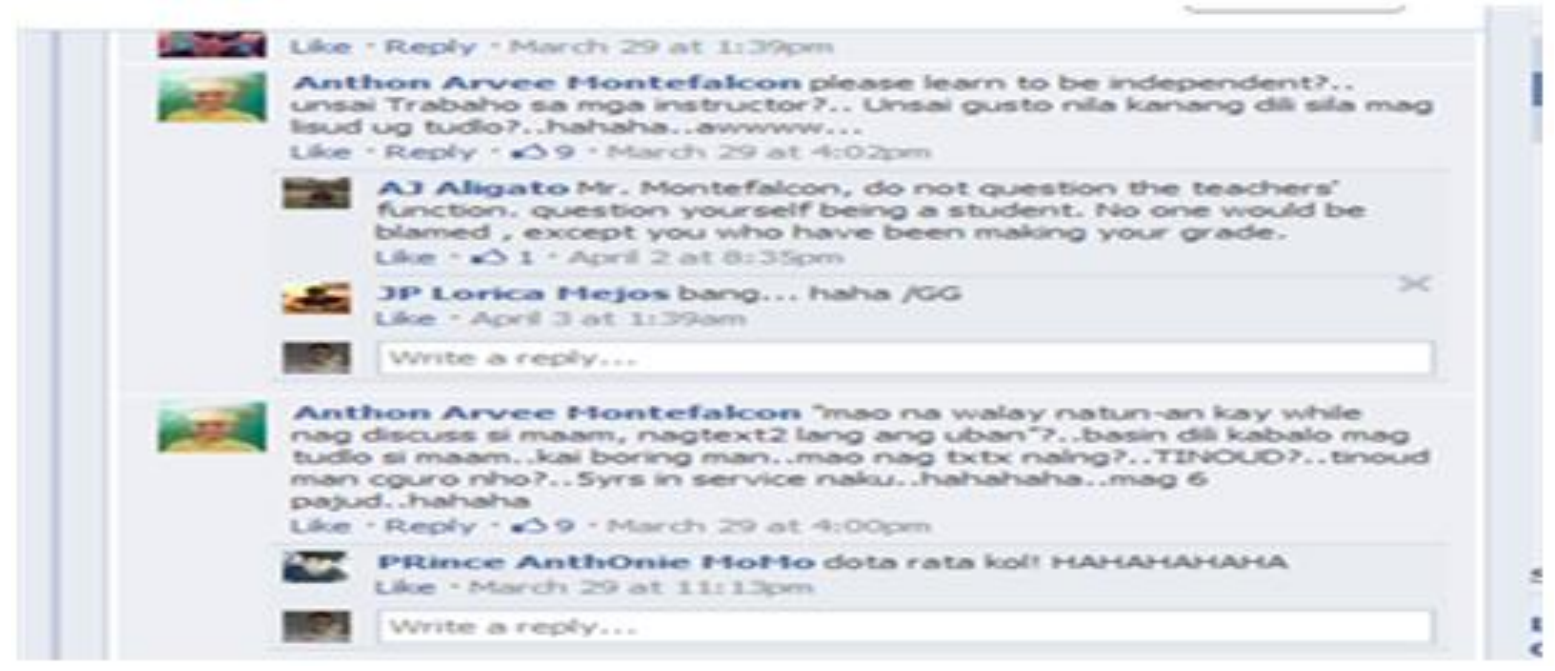

In the example cited, both reduplicated words yawyaw and txtx are in Cebuano language since writers may have difficult finding an exact English word to clearly emphasize their intense feelings. At the same time, it could be observed that the latter word txtx also exhibit another lexical feature in abbreviation.

Other reduplications muna $2 x$, nice 2 muna $2 x$, nice2, apil2, sundog 2 , and text 2 are considered under reduplication since these are understood and accepted by the readers and are also being used by them. Noticeably, they are initial syllables or syllables which are repeated with the inflection of a numerical symbol ' 2 ' which, in mathematical equations these are understood to be that the item should be counted or multiplied by 2 . 


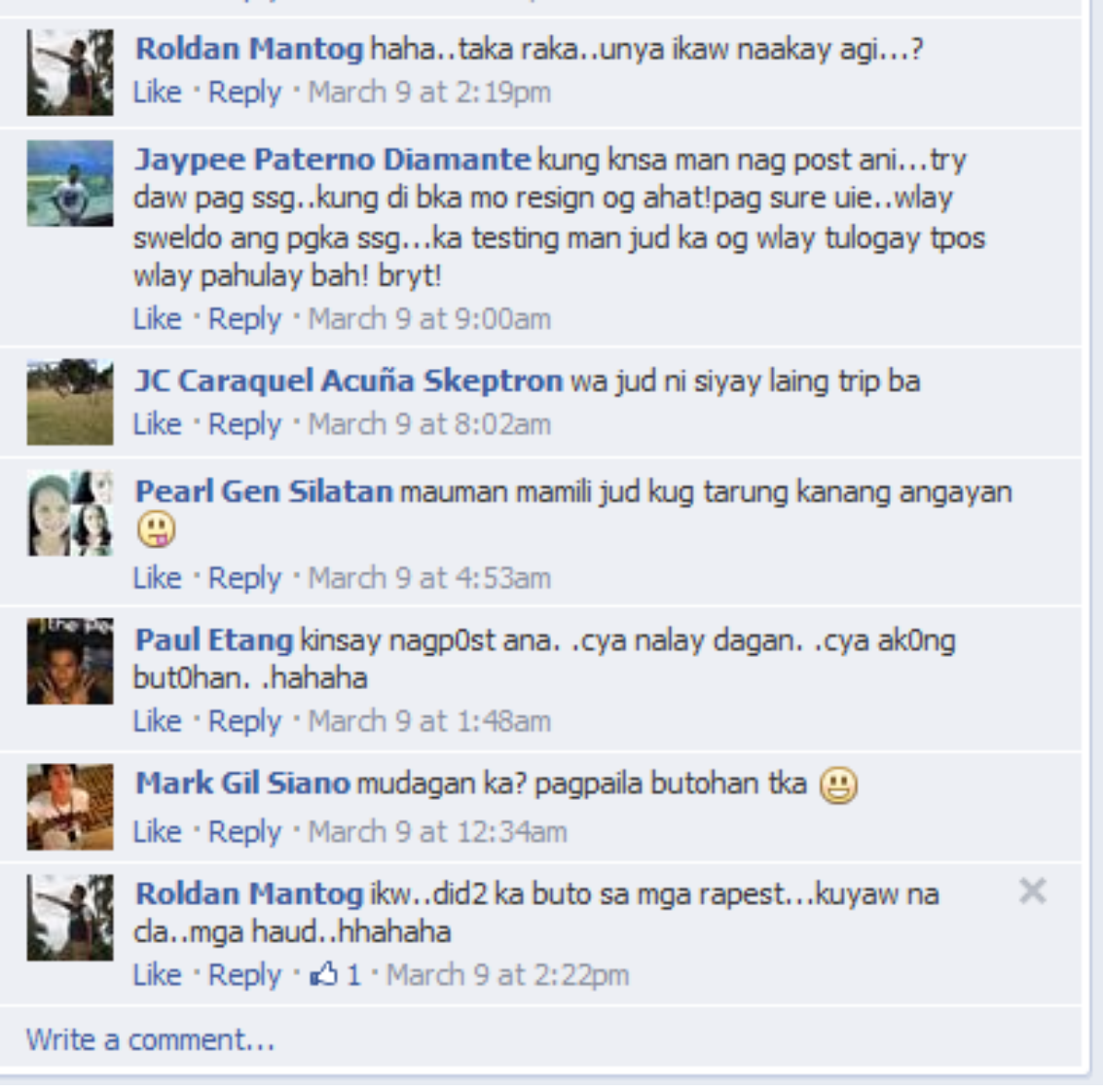

Other words like uso-uso, yawyaw, txtx are examples of full reduplication where the entire syllable is repeated in form. Uso-uso (go with the flow/bandwagon), yawyaw (murmur/vulgar expression or complaint), and txtx (doing nothing but sending text messages) are meaningful expressions of ideologies regarding freedom of expression wherein in the context of the cited post above, the issue on teacher's doing nothing in the class deserves criticism and eventual corresponding action.

However, partial reduplication is only found on words para-paraan, paulit-ulit where only a portion of the word is repeated. Katamba et al. (1996) in his book Contemporary Linguistics: An Introduction states that Tagalog reduplication affects the first consonant-vowel sequence of the base form of the word. Interestingly, Cebuano morphology exhibits a unique lexical feature where a word could be reduplicated in initial (para-paraan) and final (paulit-ulit). It must be noted that the root or base of the reduplicated Cebuano words are 'paraan' and 'ulit'.

Another common lexical feature that appeared on the study is repetition which De Beaugard and Dressler (1981) in Abdullah (2008) cited in Barbosa (2013), pointed out that repetition is used in situations where stability and exactness of content could have important practical consequences.

The comment "cya nalng dagan, cya akong buthuhan" exhibits the nature of repetition. This phenomenon existed in the forum to draw more attention, if not interest, to arouse emotion for the emphasis of intensity of feeling (Abdullah, 2008).

These feelings or emotions are further illustrated by Facebook comments like usahay madungangan, usahay pud mabawasan; cya nalay dagan, cya akong butohan; so strong, so cool; wlay tulogay tapos wlay pahulay; kung mas wise ang estudyante, mas wise ang teacher.

In the given context, "ushay" (sometimes) is used to emphasize the frequency of the act or quantity. On the other hand, "cya" (he/she) emphasizes the identity or personality of the person under discussion, while "wlay" (nothing) qualifies the degree of the act as in "wlay tulogay" (sleepless) and "wlay pahulay" (no rest). These words are repeated to simply put emphasis on the things being talked about.

Swear words only appeared in the corpora four (4) times. This suggests that students who post comments on Tate Confessions are quite apprehensive in expressing anger or just careful enough not to offend others. Swear words are rude, or offensive word, used for example, to express anger. 


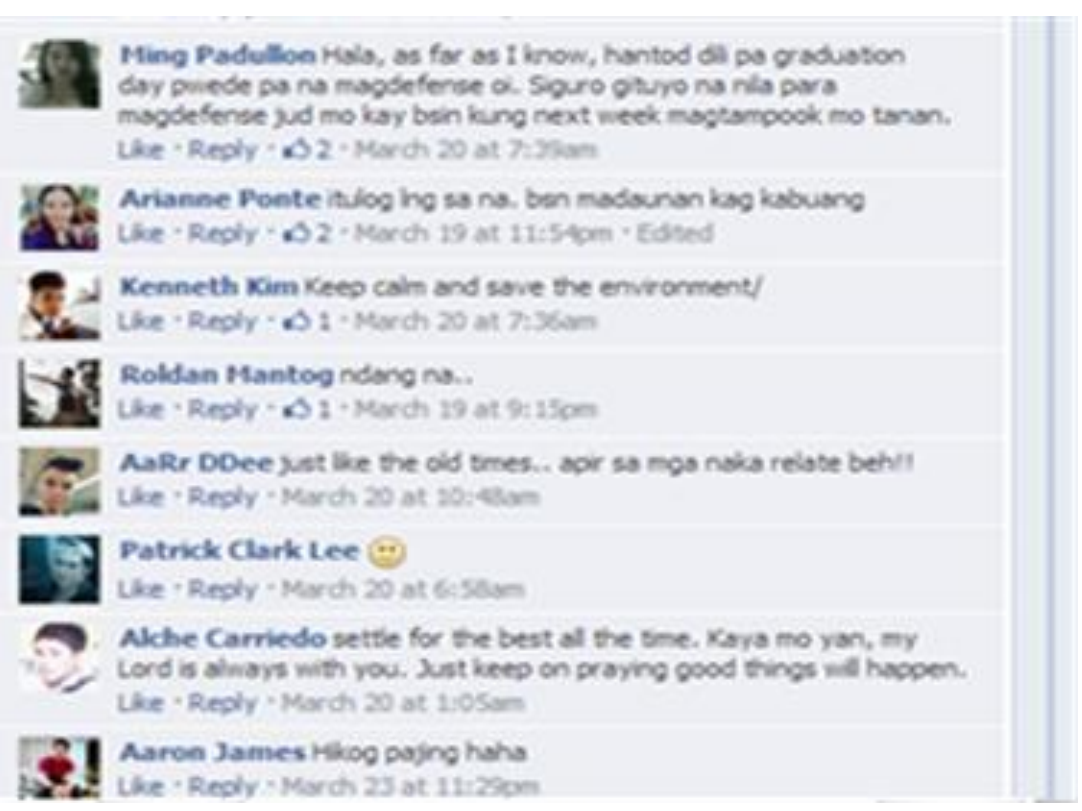

In this case, the three examples Hikog (suicide), and Ndang or Undang (stop/quit), are one in expressing an ill-advice to someone who posted the post.

The comments are deemed sarcastic, more offensive and rude since the attack is directed to a person.

In the study, other swear words like Yati (damn), Buang (idiot), Shit, Luslus (nonsense) were some of the offensive words used by the students to express their feelings or thoughts regarding a particular topic. In every day casual conversations, Yati could be heard as a form of dismay, frustration, disgust or worse, curse. The same could be true to Buang, Shit, Luslus where if looked at clearly in the context shown from the screenshot, the expressions are enumerated to create a funny yet sarcastic way of telling a commenter's idea about the topic regarding the endless cycle of thesis defense.

These words are sparingly used by the writer to express disagreement with the confessor with direct attack to a person who posted a confession even if the confessor is anonymous. However, this anonymity is not absolute since the confessor has to put a signature or nametag of the department or institute at the end of the confession. With this, the direct attack on the confessor is not entirely eliminated.

This suggests that students consider taboo as their way of communicating ideas in quite a remote manner. Expressions like "uwag" (lust) and "iyaha" (referring to penis) simply suggest a taboo that directly indicates an issue about sex.

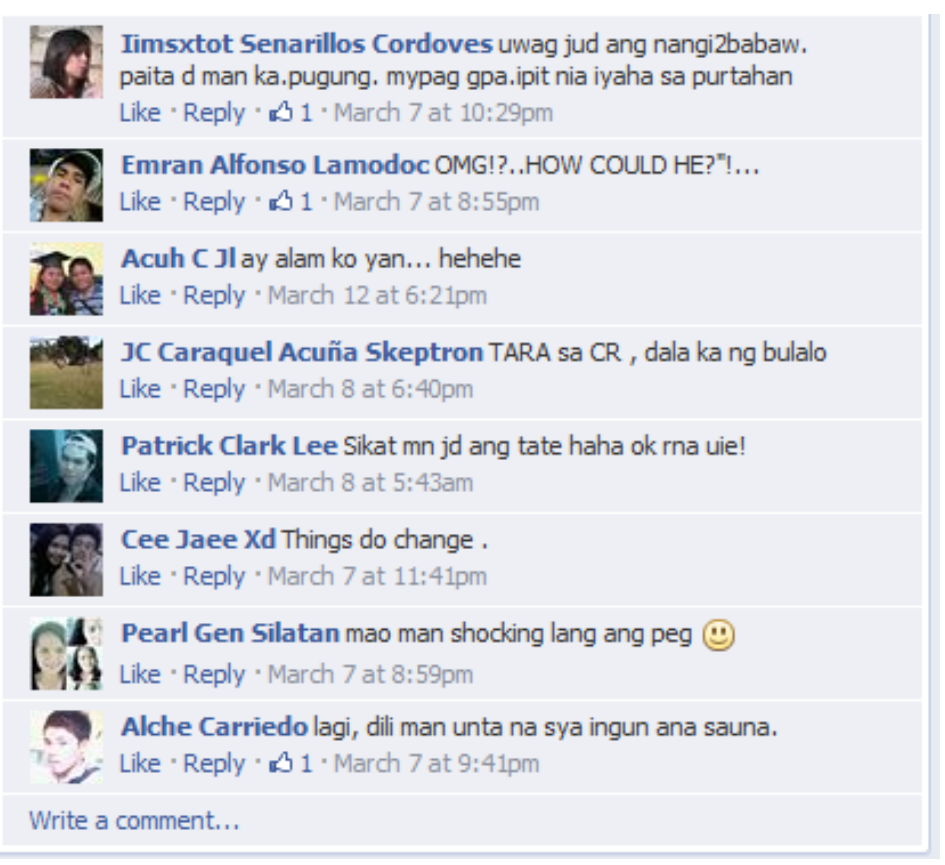


According to Al Sadi and Hamdan (2005) cited in Abdulla (2008 in Barbosa, 2013) taboos are words that many people consider offensive and shocking since they refer to sex, the body, or people's race. This is not surprising since generally authors write about sex issues in the sense that topics about sex are too sensitive, too bigoted, and too outrageous (Reisner, 1974).

\subsection{Syntactic Features on the Students'}

\section{Comments on Tate Confessions}

Under investigation in the study as well are the syntactic features in the comments of the students found in Tate Confessions. The researcher made use of the sentence classifications theorized by Radford (1997) and Quirk et al. (1985).

Quirk et al. (1972) recognized four (4) major classes into which simple sentences may be divided, and the division seems to have been made on the basis of form and function. These are statements, questions, commands, and exclamations. Quirk et al. (1972) used the following adjectives to the four sentence types just described. These are declarative (clause), interrogative (clause), and exclamatory (clause).

Radford (1987) recognizes the same types of clauses/sentences as Quirk et al. (1985) do, namely: declarative, interrogative, imperative, and exclamative sentences

The example cited, particularly stated by Roy Ponce, is an example of a declarative sentence used to convey information or to make statements. His belief that indeed a complaint on "tour" was valid as long as it was stipulated in the course outline and course syllabus.

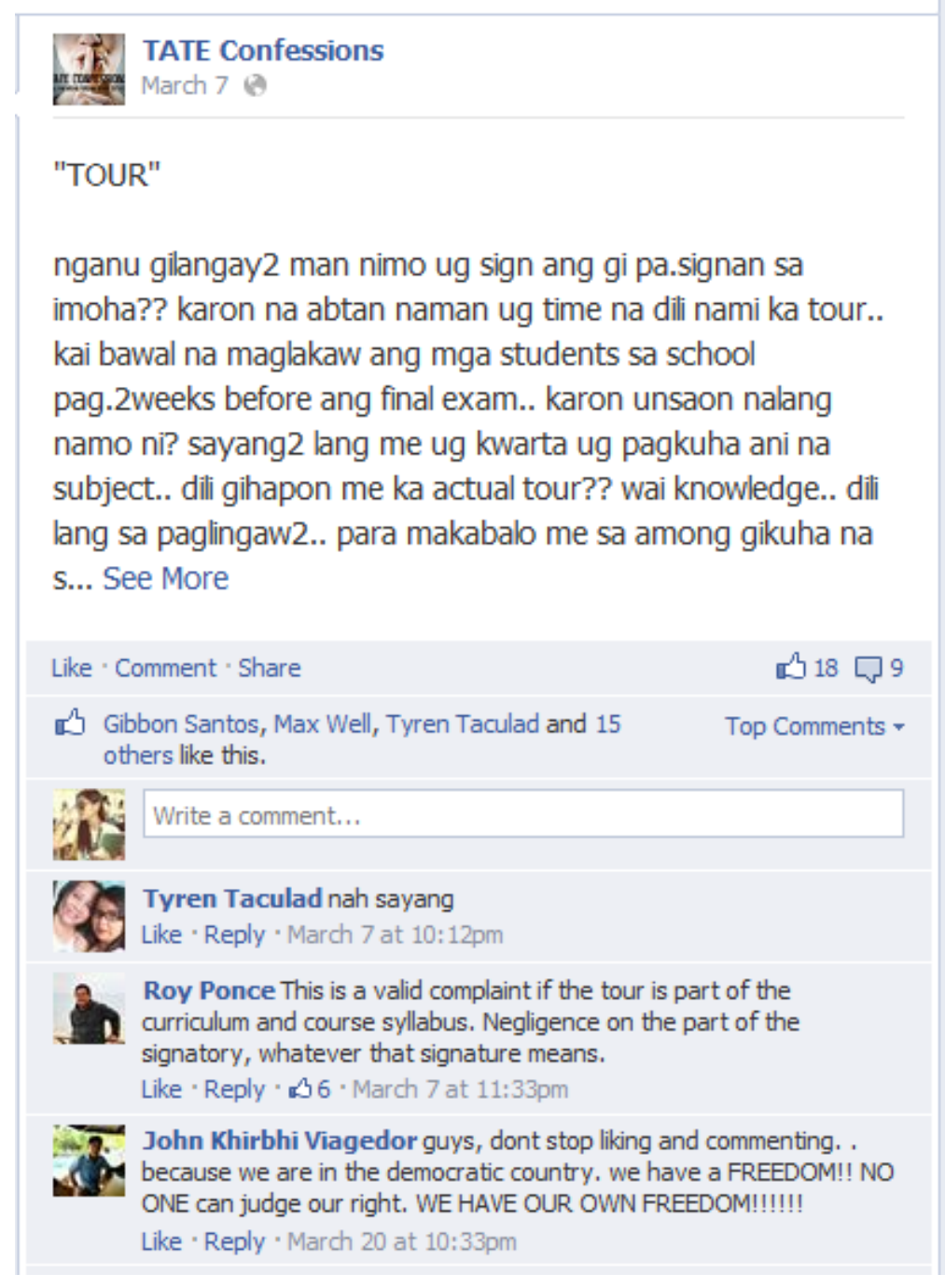

The second sentence class found on the study is imperative which is used to give directives. The sentences found under imperative class also include expressions on challenge and advice to the confessor, though the tone may vary from serious, sarcastic, and at times more on discriminatory. 
TATE Confessions

March 1 Q

\section{Conversation between a *EDIED* Instructor \& a student}

thru txt...

Student: Sir, busy ka? Naa unta ko tuyo nimo.

Instructor: o lage..1st birthday sakong anak..ngano diay?

Student: naa mn gud chiks dri sir ba, nangita ug

lingaw..unsaon mani?

Instructor: nakuha nimo ang name sa fb?

Student: oo sir..*EDITED* ang course

Instructor: cge kuhaa Ing ang no. kay kontakon ra nato na puhon..

Mao diay daghan na elicit affairs sa tate..ani diay na

cya..married pa naman c sir..wla mn Ing nakonsencya sa iyang wife ug baby...tsk..tsk..
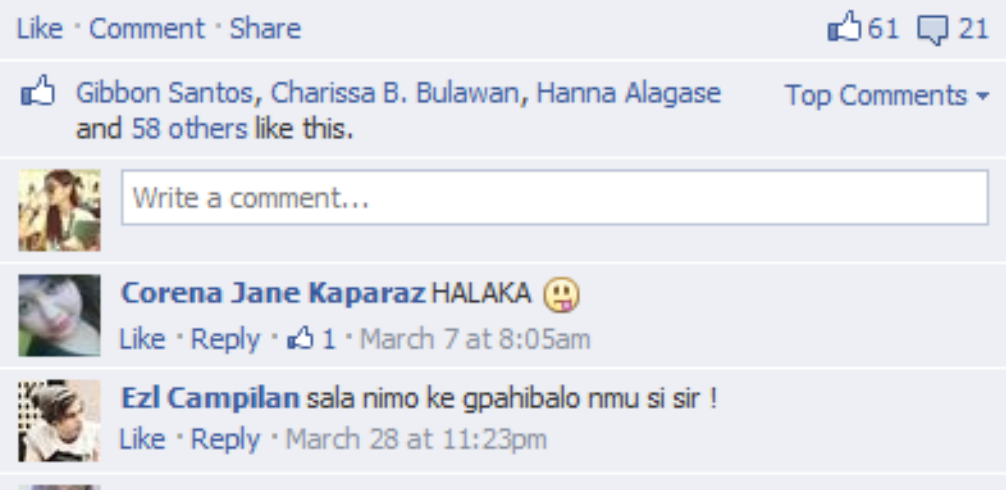

Write a comment...

Corena Jane Kaparaz HALAKA : $:$

Like * Reply " 31 - March 7 at 8:05am

Ezl Campilan sala nimo ke gpahibalo nmu si sir !

Like · Reply · March 28 at 11:23pm

The example above clearly shows commands or directives where comments have different messages to convey. "TARA sa CR, dala ka ng bulalo" is a parody of a famous line that shook national audience regarding Vhong Navarro and Deniece Cornejo. The command ridicules a person in the sex scandal issue where the incident happened in an abandoned comfort room. It could be noted also that the sentence is written in bold letters to clearly emphasize the command written by the commenter.

Radford (1997) defined exclamative sentence as a type of structure used to exclaim surprise, delight, annoyance, etc. In the study, the data revealed that exclamative sentences are used to express the commenter's strong feelings, sarcasm or discrimination especially on issues about sex, love, education, gender related topics, school politics and empowerment within students and administration alike.

The example above deals on a student blaming the confessor for being an accomplice to the indecency of the relationship since she was the bridge for such an unacceptable act. The feeling of disagreement or displeasure is clearly exemplified. This assumption affirms the theory that CDA wants to understand, expose, and ultimately resist social inequality (Van Dijk, 1988).

In addition, exclamative expressions also reveal a strong sense of contempt and shock in the issue about sex. The commenter on the example above suggests a shocking expression on the part of the person involved, issuing a comment that the incident is unacceptable or unbelievable since she knows the accused.

The fourth sentence class in the study is interrogative. Interrogative sentences are used to ask questions. In the study, the questions from comments vary in form; some require on a yes or no answer while some needed specific answer or information. 
dili lagi ko katuo sa nahitabo :): sa mga nakasabot, (dili lang nato i.mention) I hope we all learn a lesson. It's a matter of self-control.

\section{ETETD}

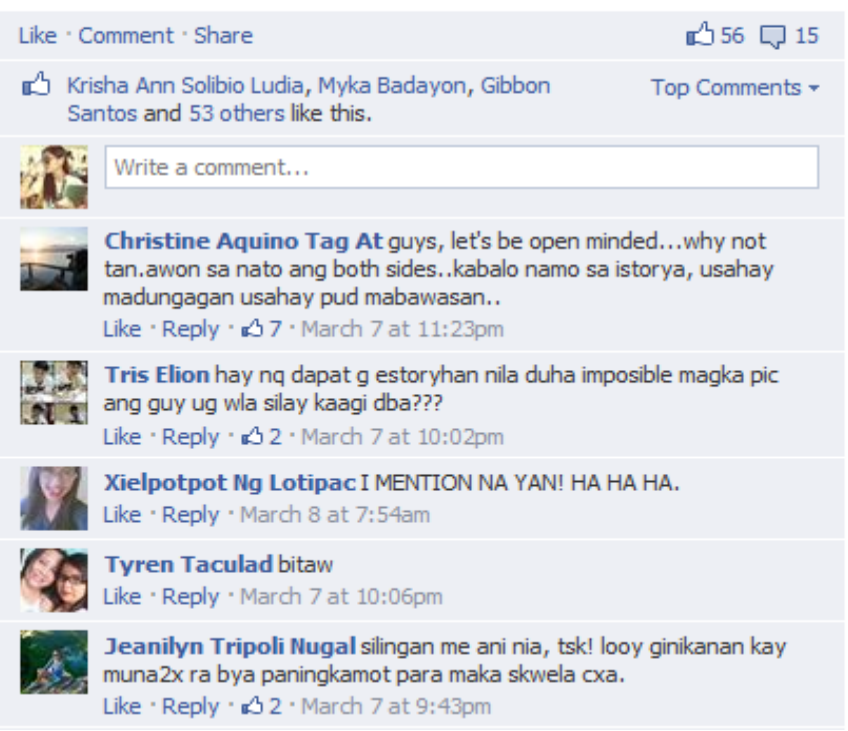

The first comment above "lingaw diay to?" is a question in form which seeks to clarify if indeed the activity was fun. In addition, it must be noted that the question after its punctuation was added with a smiley that indicates an irritating mood.

In addition, the other interrogative sentence added emphasis by adding ' $j u d$ ' as superlative even if the question was just repeated. Also, in the second example "lingaw jud!?", a double punctuation was observed and indicated that the question was very intense in seeking information. Lastly, the third question form, "Unsa ang mag activities?", affirms the mode of the two previous examples by rephrasing them, adding a specific interrogative marker 'unsa' (what) in the sentence.

It was observed that the three questions have the same purpose, that is to ask the activities and their outcomes based on the program designed by the SSG and office of the student affairs.

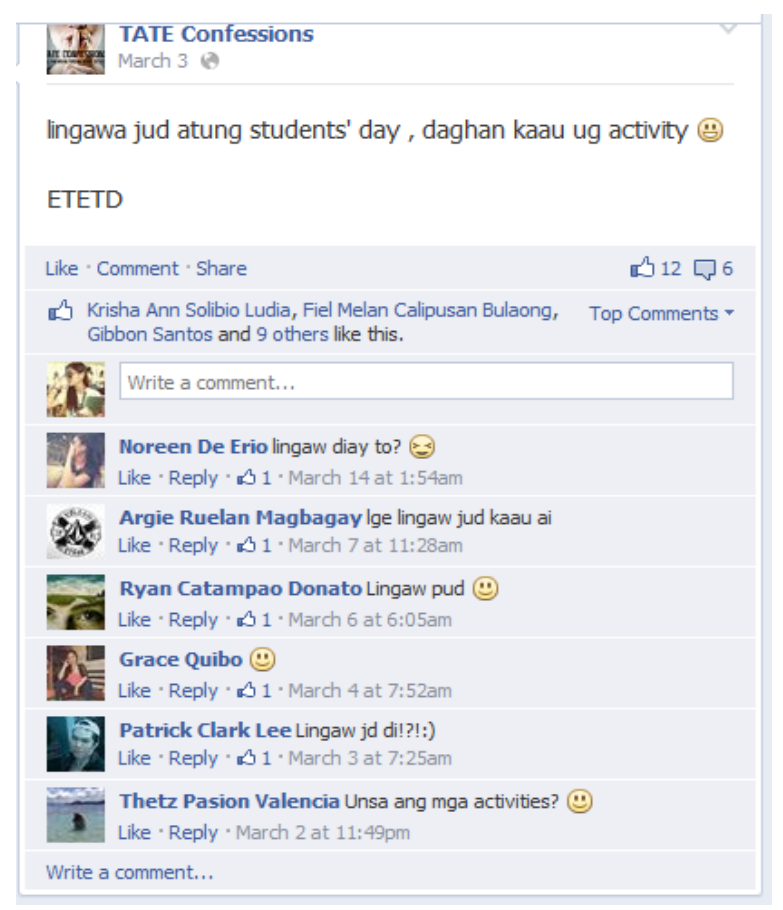




\subsection{Language Functions of the Students'}

\section{Comments on Tate Confessions}

This study explored as well on the use of language fucntions as reflcted in the students' Facebook comments on Tate Confessions. The researcher considered Halliday's (1978) view of language as a social act which is central to many of CDA's practitioners. Following Halliday (1978), Critical Linguistics practitioners view language in use as simultaneously performing three functions: ideational, interpersonal, and textual functions.

The ideational function refers to the experience of the speakers of the world and its phenomena (Fowler, 1991; Fairclough, 1995).

The cited screenshot is an example of sentences with ideational functions. The line Let's be openminded expresses wisdom on things about the confessor's experience and her idea about life that sometimes people should not easily judge someone especially if one does not really know the person. This was her idea of the incident that transpired inside the campus regarding an alleged rape case.

In addition, the ideational function of language includes topics or themes like expressing of resentment, patriotism, proverbs, and descriptive expressions where a commenter has totally a different idea, if not in accord, with the ideas posted by the confessor.

The interpersonal function of language embodies the insertion of speakers' own attitudes and evaluations about the phenomena in question, and establishing a relationship between speakers and listeners (Fowler, 1991; Fairclough, 1995). In the study, expressions regarding personal feelings, insult, religious belief, sex, and challenge are some of the sentences with interpersonal functions.

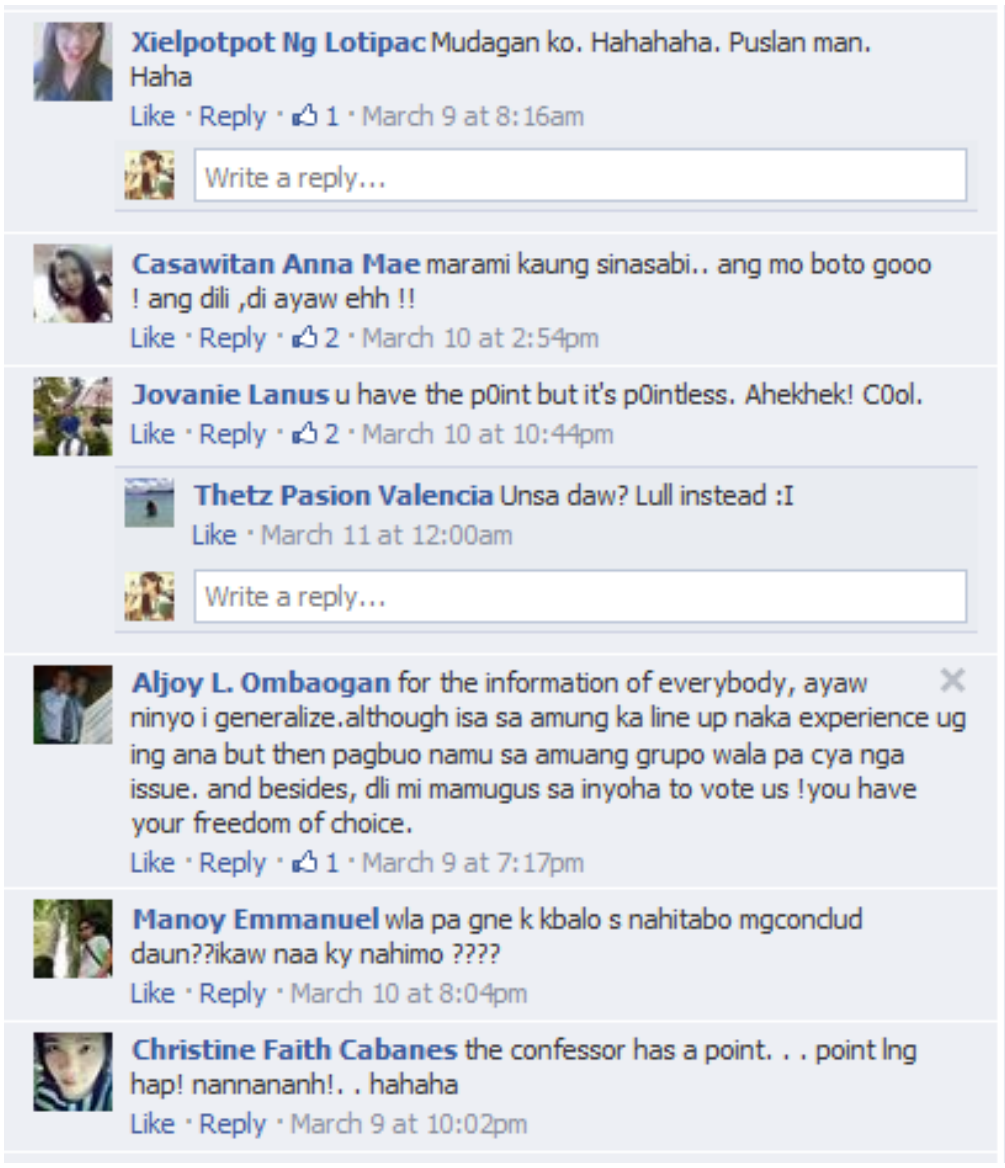

The cited screenshot is an example of sentences from a conversation with interpersonal function found in the comments on Tate Confessions. The topic centers on a confessor's complaint about the foods served by the college canteen in which some clients, specifically the 4P's scholarship recipients from typhoon Pablo, where the canteen caters their meals for the entire semester from breakfast to dinner. However, instead of gaining support from her being "allergic" on food served, the comments instead are stated in an insulting tone. This indicates that the interpersonal communication was elevated to a heated array of insulting, if not degrading ideas from other students. 
The third function of language is textual. In the study, the data revealed that there are 10 examples of sentences in four expressions like self and group glorification, expressing movie lines or titles, and expression about political matter.

Fowler (1991) and Fairclough (1995) viewed that instrumental to ideational and interpersonal functions are the textual functions. It is through the textual function of language that speakers are able to produce texts that are understood by listeners. It is an enabling function connecting discourse to the co-text and con-text in which it occurs.

The example on the next page illustrates the textual function of language. In the example "naa gud feelingon na bayot sa IARD Department", a gender-biased expression is included after the confessor has freely expressed his annoyance and irritating impression on a gay.

The comments at first seem to agree with him, but in the later part, the comments became harsh when the confessor mistook the IARD as a department when in fact the confessor belongs to the same institute.

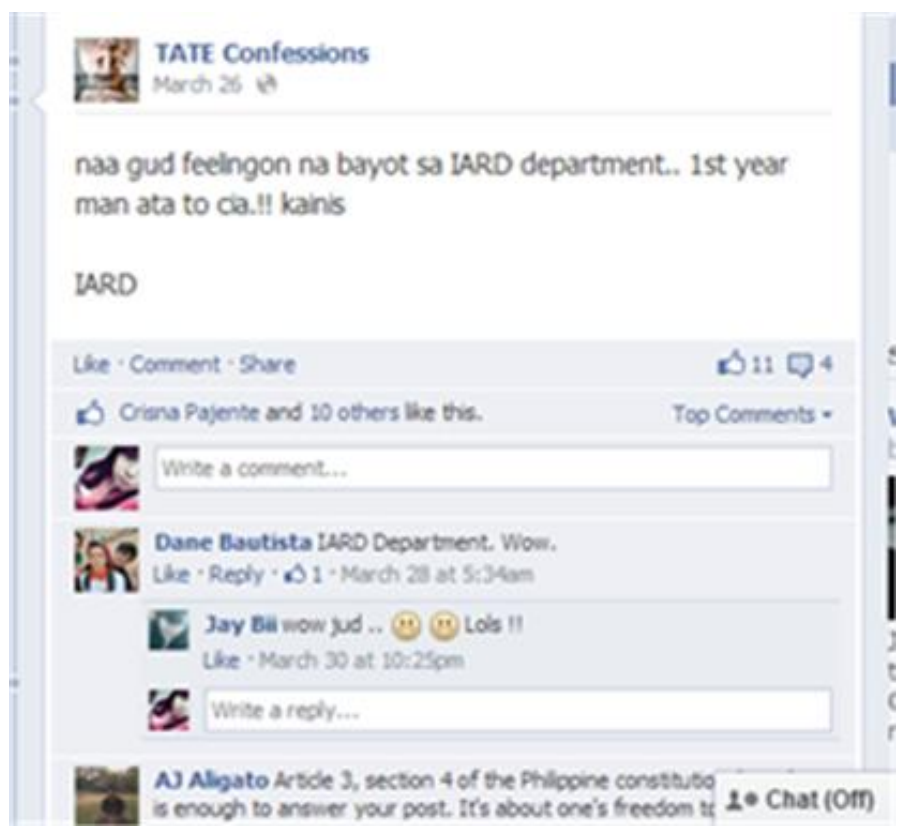

The textual function of language demonstrated in the text is an example of co-text and con-text situation where the written idea is observed in a context that eventually leads to a contextual discussion on the issue. The comments at first focused on the theme but later on shifted to the text where it was realized that IARD (Institute of Agriculture and Rural Development) is not a department but an institute, as wrongly or could be unwittingly encoded by the confessor.

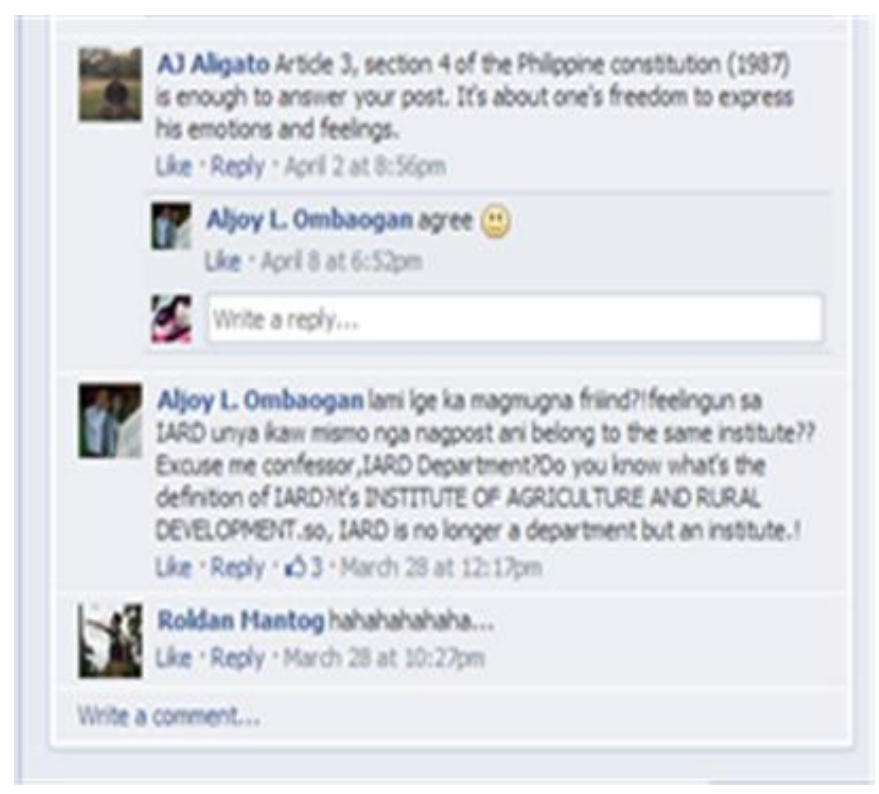




\subsection{Lexical and syntactic features that determine ideologies of the students' comments on Tate Confessions}

The study also deals with the lexical features that determine the ideologies of the students. Lexicon refers to all the words and phrases used in a language or what a particular person knows. It also states that lexicon is an alphabetical list of words with meanings, especially on a particular subject matter or in a particular language. Generally, lexicon is a catalogue of a given language's words. Items in the lexicon are called lexemes or word forms. Lexemes are not atomic elements but contain both phonological and morphological components.

The conversation above was taken from the confession of a student who is in disbelief of an alleged rape that happened in the campus. The confessor knew the person very well since the accused is a familiar figure in the college, (affiliated to ROTC and in Guidance Office, and is running for VP in the SGG elections). The lexical features taken into consideration are 'uwag' (lust) which clearly indicates the ideology about sex. "Uwag" is a taboo expression which is considered offensive. This supports the claim of Abdullah (2008) in Barbosa (2013) in her study about taboo expressions in graffiti writings of the students in University of Southern Mindanao. Her findings reveal that taboo expressions are generally sexual in tone, like oten (penis) and pisot (uncircumcised). This is also true to the case of Facebook comments of students on Tate Confessions where taboo expressions are directly associated to sex.

Ideological contents of the students Facebook comments on Tate Confessions based on the syntactic features are also explored in this paper. In the study, CDA examines the discursive participants' choices of words and metaphors in relation to their relational, experiential, and expressive values, with these choices encoding assumption about power (Orellana, 1996).

Declarative sentences mostly focused on ideologies about discrimination on education, stereotyping, physical appearance, power, sex, and love.

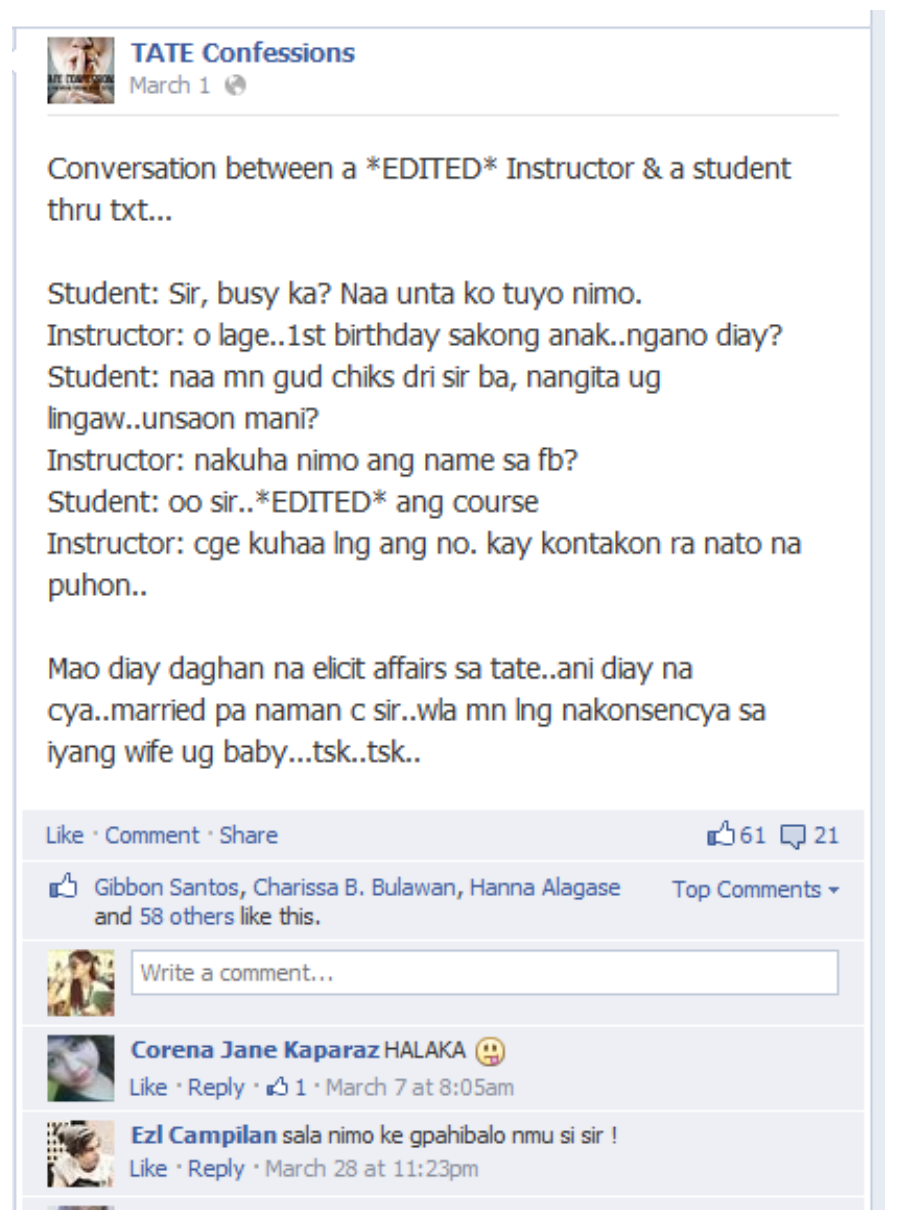

The comment by above "dugay nman ni na issue. panahon namu. Trending nani", confirms a statement that love affair between a student a faculty has long been observed in the campus (the confessor is an alumni and wass a former student of the researcher). 
This means that the ideology on love, if not discrimination on the part of the commenter is implicitly expressed in his words where it could not be assumed that he consents of dissents the said affair.

The exclamative forms have ideologies pertained to discrimination in education, physical appearance, faith or religion, power, or giving warning or advice.

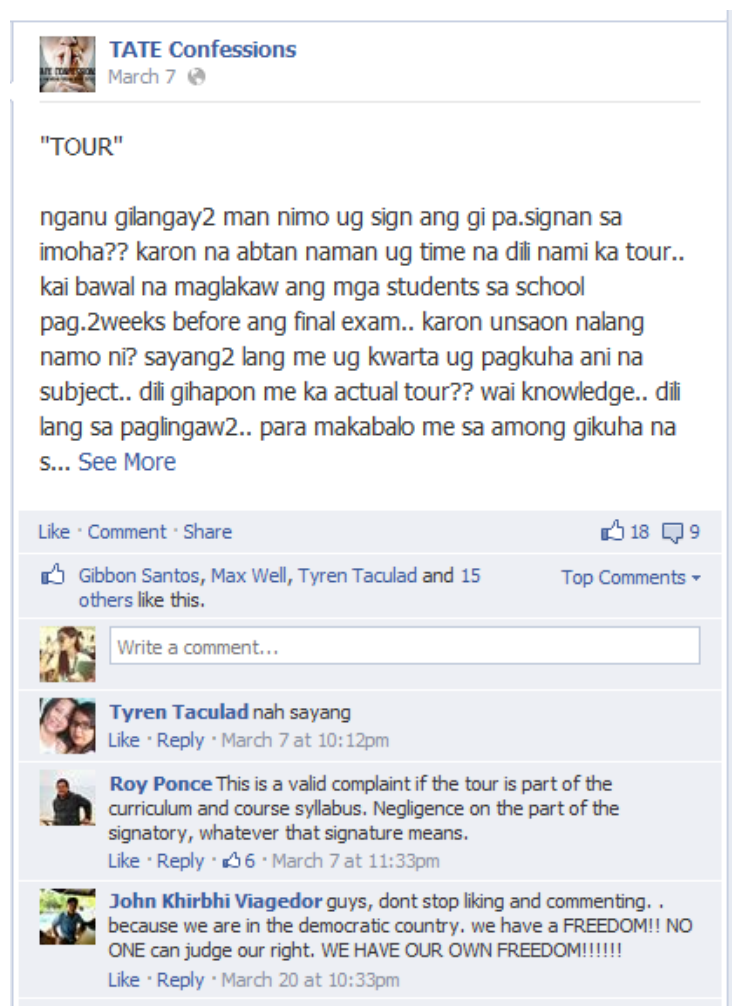

The above example shows the reality of exclamative sentence in passionate manner of revealing his ideology on power, or in particular, political or human rights that also students should have, thus giving them the license to embrace empowerment.

The interrogative class focused only on ideologies about discrimination in education, physical appearance, and power. Lastly, the imperative class has common ideologies on sex, life, environment, discrimination on education and stereotyping, and faith or religion.

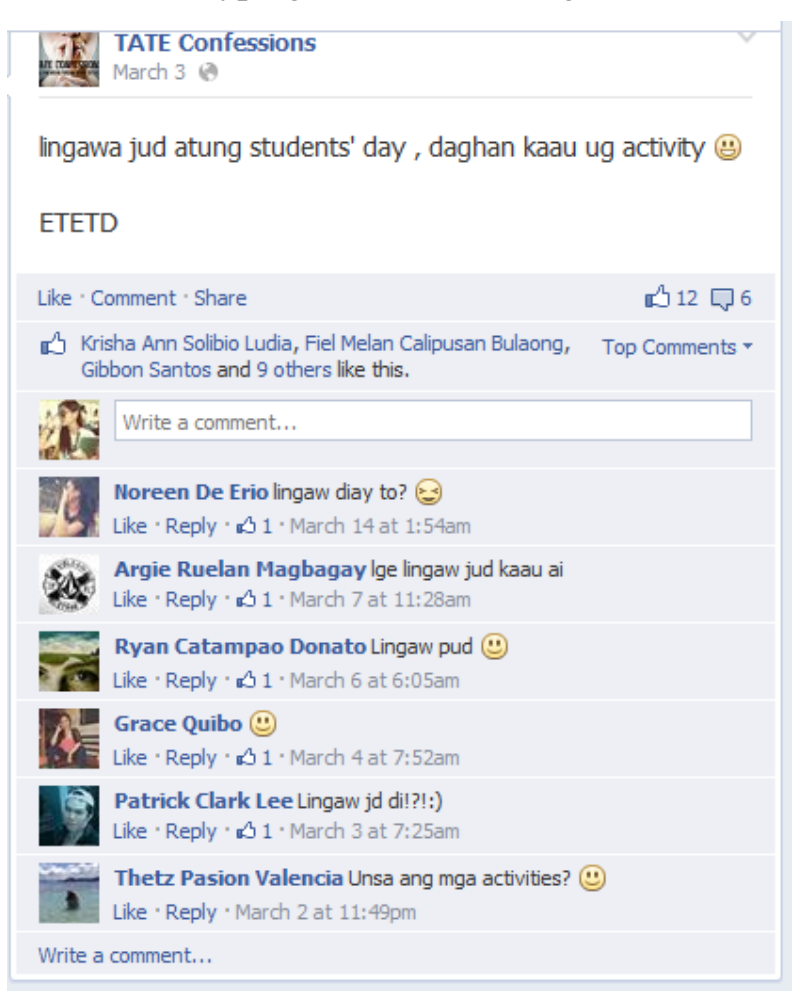


The conversation above is almost dominated by questions. The ideology on power and discrimination in the context of education is clearly visible. If one knows the background, the study activity was staged with a very lousy atmosphere where only few students have attended. In relation to that, the comments were meant to ridicule the said event since the students are quite discriminated by the SSG for not giving them the services they needed, particularly in the context of financial context and in the aspect of accomplishments. These ideologies are hidden and that the commenters are actually looking for fairness and justice for all the payments they contributed to the said student organization.

The fifth question that the study sought to answer is on the ideological contents of the students' Facebook comments on Tate Confessions. The study presents the underlying ideologies found in the comments on issues about discrimination, education, love, sex, self and collective identity, faith or religion and discrimination based on physical appearance.

\section{Ideological content of the students' Facebook comments on Tate Confessions}

The examples below are examples of discrimination based on education. The comments reveal that the confessor is on the wrong side of the issue. The first two comments castigated the confessor for being too demanding and arrogant on her confessions specifically that the students are to be blamed for their shortcomings.

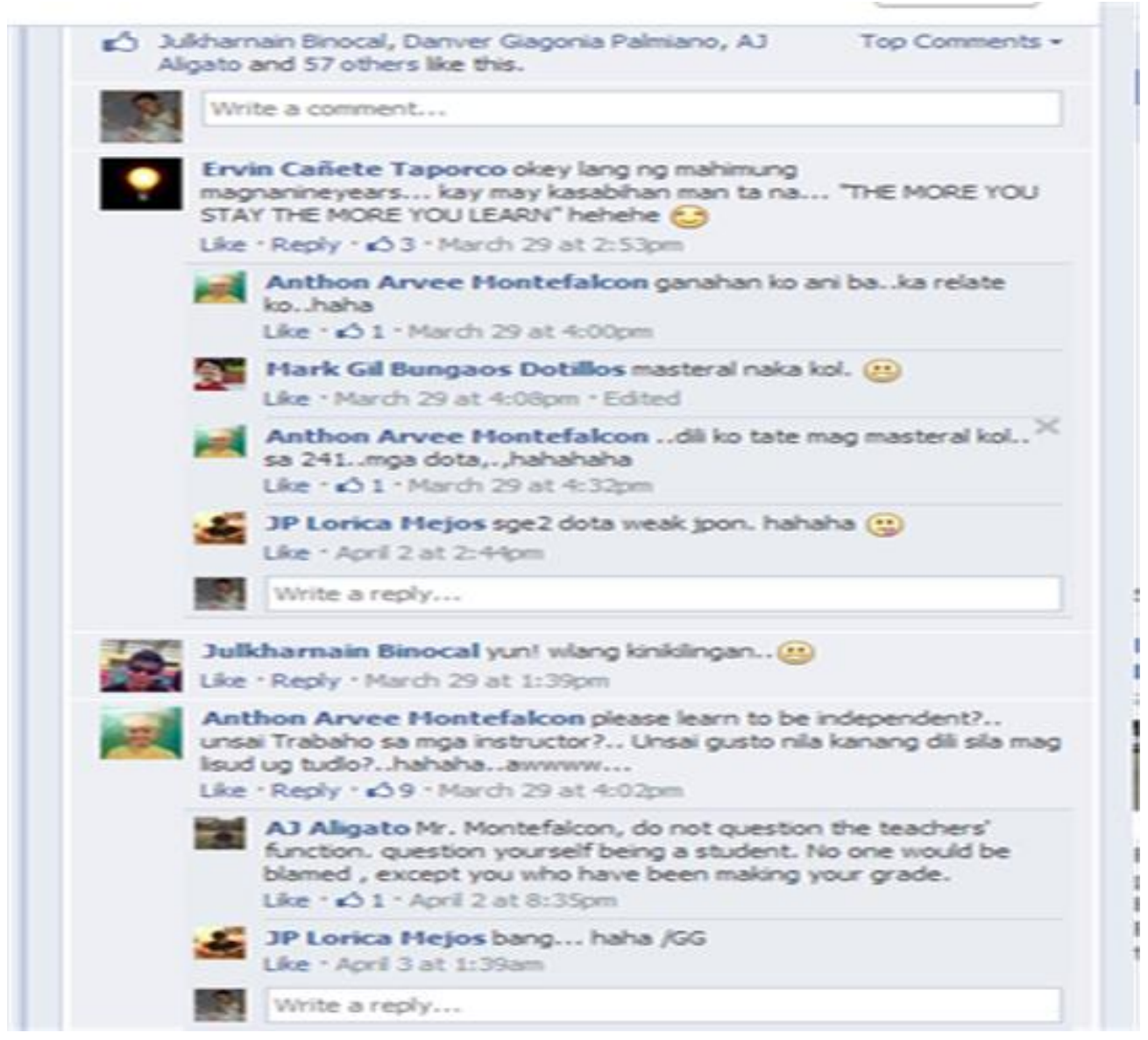

The conversation presented affirms the point of van Dijk (1998) that groups (like teachers) may more or less control other groups (students), or only control them in specific situations or social domains.

In this case, the confessor is believed to be a faculty who tried to manipulate the students. This is a real life scenario in the college, where some students are controlled and are manipulated by some teachers. Undocumented accounts say that many faculty members threat students by using their grades; others even file legal complaints to students who posted comments in Facebook. This discrimination on education also touches the ideology of power. Moreover, dominated groups may more or less resist, accept, condone, comply with, or even find the discrimination normal (cited in Barbosa, 2013).

The ideology regarding sex is a hot issue in the college, specifically the alleged rape case which transpired sometime in February 2014 involving two Criminology students of the Evening Program. 


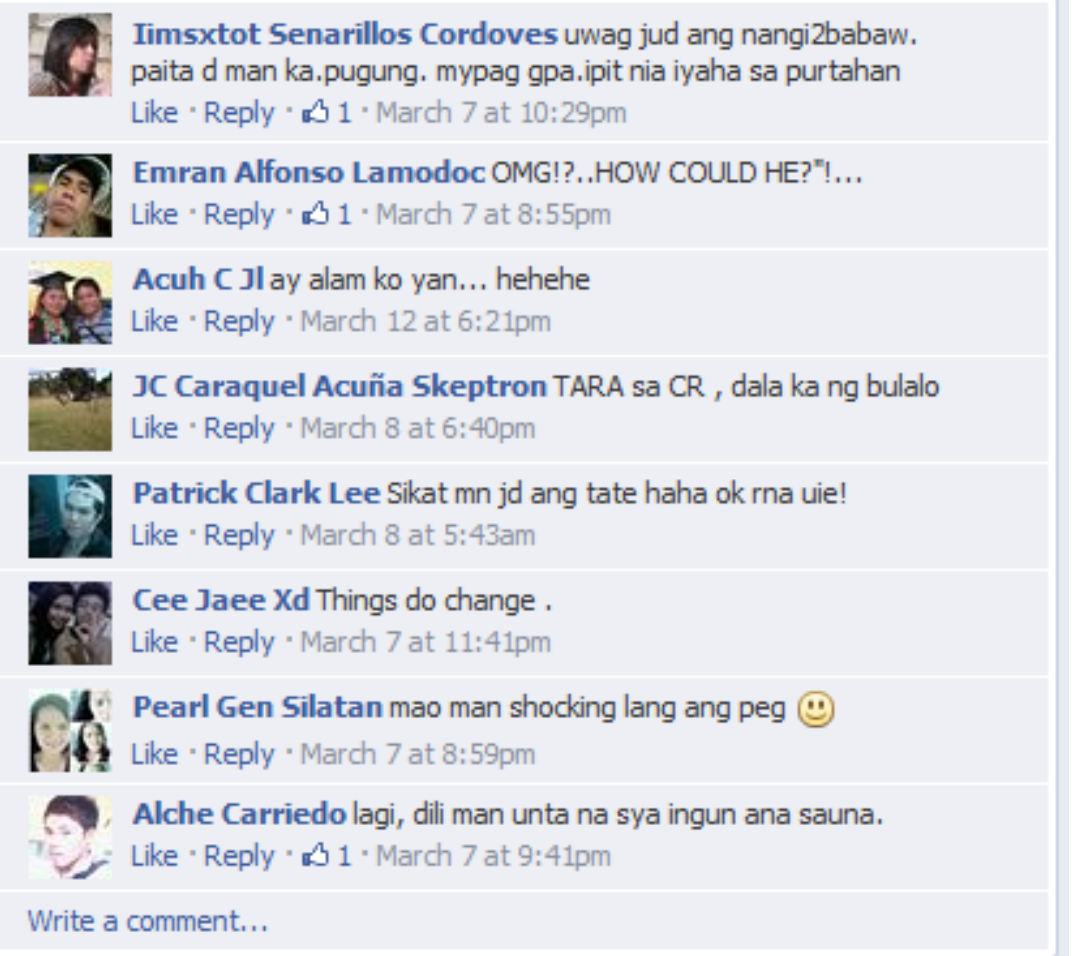

The confessor anonymously wrote about the person involved and even the incident at hand. This ideology is taboo in nature since the comments directly mentioned words that are offensive and shocking, or even unacceptable in an academic society like DOSCST.

The first comment "uwag" (lust) is a very rude word that the one who reads it would feel or consider the word very offensive and foul. Others found it funny and commented in the succeeding conversations sarcastically. The last commenter was shocked and has the feeling of disbelief in the sense that he could not imagine an ROTC officer and president of an organization under Guidance office could do such a crime.

Other ideologies on stereotyping (They are rich your[e] poor), faith and religion (always recognize GOD for his unwavering guidance and love... HIS unending goodness.); power (Guys, pag. comment ug pag. like mo... FREEDOM nato ni); on life (Things do change.); and love (love it) also commonly appear on students comments on Tate Confessions. These reveal that language has become the tool for expressing ideologies by students in DOSCST.

This confirms the theory of Van Dijk (1995) that ideologies are typically, though not exclusively, expressed and reproduced in discourse and communication, including non-verbal semiotic messages, such as pictures, photographs and movies.

As found in the data collected, Tate Confessions and various comments are ideological by nature. These comments are expressed according to topics, or even according to the personality of the confessor since the department where the confessor belongs has been identified the entire post.

In addition, the education issues commonly imply the ideologies on discrimination and power, where the dominant group (teachers) and the inferior ones (students), conflicts arising from one department or institute, and students versus student organizations are at the center of discourses. The defining features of CDA are its concern with power as a central condition in social life, and its efforts to develop a theory of language that incorporates this as a major premise (Iedema, 1997; Iedema and Wodak, 1999; Muntigl et al., 2000). These are seen real in the study since the ideologies in the Facebook comments of the students are mostly implied in their comments, where others are bold enough to voice their dissents or complaints, while others, fearing to fail or be involved in more complicated situations, remain silent and just conform with the social environment where they belong.

\section{Summary, ConClusion, AND RECOMMENDATIONS}

This chapter presents the summary, conclusion, and recommendation of the study based on the results gathered. 


\subsection{Summary of Findings}

The following findings are drawn after the interpretation and analyses of the data:

1. The Facebook comments of DOSCST students exemplify lexical features such as onomatopoeia, loan words, abbreviations, acronyms, reduplication, repetition, swear words, taboo words and expressions. Onomatopoeia generally exhibits humour, loan words, repetition, and reduplication used to emphasize ideas, swear words and taboo words which are discriminatory. Mostly, these lexical items are written in Cebuano language, except for the case of loan words where a Cebuano affix is attached to an English word, and in the peculiar case of reduplication where a numerical symbol ' 2 ' is added next to the syllable(s) which aims to be repeated.

2. On the syntactic features, the comments of students found on Tate Confessions have the forms of short statements, questions, quotes, and terse statements. These are observed on topics about education, power or politics, sex, and even in faith or religion. Four sentence classes were determined such as declarative, imperative, exclamative, and interrogative.

3. The three language functions determined are ideational (composed of expressions on wisdom, humour, resentment, patriotism, human rights, proverbs and descriptions); interpersonal (expressing personal feelings, insult, faith, sex, and challenge), and textual (expressing glorification, movie title, and political content).

4. (a) The lexical features that determine ideologies of students in Tate Confessions include: taboo (sex), loan words (education, self identity), swear words (discrimination on state of mind), repetition (discrimination on ability), reduplication (discrimination on ability), acronyms (education), and abbreviations (on self identity)

(b) The syntactic features found on students Facebook comments are the following: declarative (discrimination based on education, stereotyping, power, sex, self and group identity, life, and love), interrogative (discrimination based on education, physical appearance, power) imperative (discrimination based on education, stereotyping, faith, power, sex, life, environment), and exclamative (discrimination based on education, physical appearance, faith, life, love, advice or warning, power).

5. The common ideologies found on students Facebook comments on Tate Confessions are discrimination based on education, physical appearance, stereotyping, faith or religion, power or political views, sex, self and group identity, life, and love.

\subsection{Conclusion}

Based on the gathered findings, the following conclusions are drawn.

1. Students use different lexical features on their comments.

2. To express their ideologies, students use declarative, imperative, exclamative and interrogative sentence classes.

3. Students post comments to express ideas and feeling for gratification.

4. The Facebook comments of students in Tate Confessions convey thoughts and feelings, ideas and emotions which are varied like education, sex, faith or religion, academic concerns, school activities and even personal judgements or ideas about an issue.

5. The Facebook comments of students in Tate Confessions carry ideologies on power, discrimination (education, physical appearance, stereotyping) sex, self or group glorification, faith or religion, and even on love were expressed in both lexical and syntactic contexts.

\subsection{Recommendations}

The researcher made the following recommendations based on the findings and conclusions of the study.

1. English and language teachers should remind students to be clear on the message that they are posting by writing correct spelling, punctuations, and sentence crafts to avoid misunderstanding and confusion that would lead to amore heated arguments. 
2. The instructors should inform students to be responsible for every word they post on Facebook for these could "make or break" themselves and the college as a whole.

3. Language and English instructors should remedy the errors in spelling and grammar of students since this phenomenon is currently observed inside the classroom.

4. Teachers should not dominate students nor manipulate them since it would only affect the students' both emotionally and academically.

5. Teachers and students should discuss issues on grades, even on sex and love whenever necessary in a positive perspective to avoid conflict and discrimination.

6. The Administration should likewise support endeavours like seminars enhancing English faculty on their strategies and methods in teaching English and language to remedy problems in English language learning and usage.

7. The Administration should also look into the lens of rights, student empowerment and freedom of expression among students in response to responsible use of Facebook to achieve unity and cooperation within DOSCST.

8. The study could be a basis for the guidance and counselling office to intervene problems in behaviour of students who are particularly offensive and rude, and oftentimes more sarcastic than being careful on their expressions shared on social networking sites.

9. Future researches especially on ideologies are recommended to investigate the trends in modern age and in the digital world, particularly with the use of social networking sites where new groups emerged, in which the CDA frameworks of van Dijk (1998) could be best applied.

\section{REFERENCES}

[1] Atkinson, P., Davies, B., and Delamont, S. (1995). Discourse and Reproduction. Essays in Honor of Basil (1996). Models of Understanding Text. Bernstein.

[2] Barbosa, E. (2013). Critical Discourse Analysis on Students' Graffiti Writings Unpublished Masters Thesis. Language Program, College of Arts and Sciences, University of Southeastern Philippines.

[3] Billig, M. (1996). Arguing and Thinking: A Rhetorical Approach to Social Psychology, 2nd ed. Cambridge: Cambridge University Press.

[4] Billig, M. (1997) 'The Dialogic Unconscious: Discourse Analysis, Psychoanalysis and Repression', British Journal of Social Psychology, 36(2): 139-59.

[5] Billig, M. (1999a) 'Whose terms? Whose ordinariness? Rhetoric and Ideology in Conversation Analysis', Discourse and Society, 10(4): 543-58.

[6] Billig, M. (1999b) 'Conversation analysis and the claims of naivity', Discourse and Society, 10(4): 572-6.

[7] Billig, M. and Simons, H.W. (1994) 'Introduction', in H.W. Simons and M. Billig(eds), After Postmodernism. Reconstructing Ideology Critique. London: Sage Publications.

[8] Bourdieu, P. (1989) Academic Discourse. University of California Press. Linguistic Misunderstanding, Ideology and Professorial Power, Cambridge: Polity Curriculum. London: Routledge and Press

[9] Bourdieu, P. and Wacquant, L.J.D. (1996) An Invitation to Reflexive Sociology. Cambridge: Polity Press.

[10] Boyd, D. (2011). Embracing a Culture of Connectivity. Berkman Center for Internet and Society, Harvard University.

[11] Cain, J. (2012). Using Facebook as an Informal Learning Environment University of Kentucky, 789 South Limestone, Lexington, KY 40536-0596.

[12] Chilton, P. (2008). Analysing Political Discourse. Theory and Practice. TJ Intermational Limited, Padstow, Cornwall.

[13] Chomsky, N. (1995). The Minimalist Program. The MIT Press, Cambrige, Massachussets.

[14] Chouliaraki (L). \& Fairclough (N.). (1999)Discourse in Late Modernity: Re-Thinking Critical Discourse Analysis. Edinburgh: Edinburgh University Press.

[15] Chouliaraki, L. (1995) 'The constitution of ethnographic texts in Socialsc ientificdiscourse: "real-ist" and "polyphonic" representations', Interface. Journal of Applied Linguistics 10(1): 27-46.

[16] Chouliaraki, L. (1998) 'Regulation in "progressivist" pedagogic discourse: individualized teacher-pupil talk', Discourse and Society, 9(1): 5-32.

[17] Chouliaraki, L. (1999) 'Media discourse and national identity: death and myth in a news broadcast', in M. Reisigl and R. Wodak (eds), The Semiotics of Racism. Vienna: Passager Verlag. 
[18] Chouliaraki, L. (2002) 'Capturing the "contingency of universality": some reflections on discourse and critical realism', Social Semiotics 12(2): 84-114.

[19] Chouliaraki, L. and Fairclough, N. (1999) Discourse in Late Modernity: Rethinking Critical Discourse Analysis. Edinburgh: Edinburgh University Press.

[20] Crystal, D. (2002). Language and the Internet. University of Cambridge Press, United Kingdom.

[21] Crystal, D. (1992). Introduction to Linguistics. Penguin English. The University of California.

[22] Fairclough (N.). 2004. Critical Discourse Analysis in Researching Language in the New Capitalism: Overdetermination, Transdisciplinarity and Textual Analysis. In: Harrison (C.) \& Young (L.) eds. Systemic Linguistics and Critical Discourse Analysis. London.

[23] Espinosa, D. (2001). Discourse Analysis of Language Teachers. ERIC Digest. Retrieved on January 2013 from www.cal.org.ericcll.

[24] Fairclough, N. (2010). Critical Discourse Analysis. The Critical Study of Language: Longman.

[25] Fairclough N. (1992). Critical Language Awareness. New York: Longman.

[26] Fairclough, N. (1992). Discourse and Social Change. Cambridge: Polity Press.

[27] Fairclough, N. (2001). The Dialectics of Discourse. Textus, 14,231-242.

[28] Fairclough, N., Wodak, R. (1997) Critical Discourse Analysis, in T. van Dijk, as Social Interaction. London: Sage Publication.

[29] Fairclough, N, (1995) Media Discourse, New York: Edward and Arnold

[30] Fairclough, N. L. (1995a). Critical Discourse Analysis: The Critical Study of Language.Harlow, UK: Longman

[31] Fairclough, N. L. (1995b). Media Discourse London: Edward Arnold.

[32] Fairclough, N. L. and Wodak, R. (1997 Critical Discourse Analysis. In T. A. van Dijk (ed.) Discourse Studies. A Multidisciplinary Introduction, Vol. 2. Discourse as Social Interaction (pp. 258-84). London: Sage.

[33] Feenberg, A. (2003). Critical theory of Technology. Oxford University Press.

[34] Fowler, R. Hodge, B., Kress, G., \& Trew, T. (1979). Language and Control. London Routledge.

[35] Fowler, R. (1991). Language in the News Discourse and Ideology in the Press London: Routledge and Kegan Paul

[36] Knight, P. (2006). Learning and Teaching English: A Course for Teachers. Oxford University Press.

[37] Fowler, R. and B. Hodge (1979). Critical linguistics. In R. Fowler et al (Eds.). Language and Control. London: Routledge and Keegan Paul. pp. 185-213

[38] Fowler, R. (1996). Linguistic Crticism. Oxford: University Press.

[39] Gee, J. P. (2004). Situated Language and Learning. A Critic of Traditional Learning. Routlegae. New York.

[40] Gerolimos, M. (2011). Academic Libraries on Facebook. Analysis on User's Comments. D-Lib Magazine 17(11/12).

[41] Halliday, M.A.K. (1994). Introduction to Functional Grammar. London: Edward Arnold. London

[42] Heather, D. et al. (2009). The Relationship between Facebook Use and Grade Point Average, the University of North Carolina at Chapel Hill

[43] Jakobson, R., (1960)"Linguistics and Poetics", in T. Sebeok, ed.,Style in Language, Cambridge, MA: M.I.T. Press.

[44] Kolek, E. A. \& Saunders, D. 2008. Online Disclosure: An Empirical Examination of Undergraduate Facebook Profiles. NASPA, 45(1), 1-25.

[45] Lakoff, R. (1973), Language and Woman's Place, Language in Society, Vol.2, No. (Apr. 1973), 45-80. Cambridge University Press.

[46] Lakoff, R. T. (1990). Talking Power. The Politics of Language. New York: Basic Books.

[47] Lakoff, R.T. (1990). Talking Power. The Assymetrical Situation. In I. Markova Politics of Language. New York: basic and K. Foppa (eds), Assymetries in Books

[48] Lakoff, G., Johnson, M. (1980), Metaphors We Live By. Chicago: University of Chicago Press

[49] Lemke, J. (1995) Textual Politics. London: Longman

[50] Longworth, L. (2003). Lifelong Learning in Action. Transforming Education in $21^{\text {st }}$ Century. Kogan Page Limited.

[51] Lyons, J. (1970). Introduction to Theoretical Linguistics. London and New York. Cambridge University Press. 
[52] Mabandos, Vina Grace(2013).TC Dissected: The Two faces of Tate Confession, Ang Sidlakan, Volume 28, Number 1, DOSCST, Mati City, Davao Oriental

[53] Mac Croskey, J (2007). An Intorduction to Rhetorical Communication. Allyn and Bacon

[54] McCarthy, T. (1993). Ideals and Illusions. Reconstruction and Deconstruction in Contemporary Critical Theory. MAssachussets Institute of Technology.

[55] Orellana, M. F. (1996). Negotiating Power Through Language in Classroom Meetings. Linguistics and Education.

[56] O'Grady, W.; Dobrovolsky, M. \& Katamba, F. (1996). Contemporary Linguistics. Third edition. London: Longman. pp 18-91.

[57] Quan-Haase, A., \& Young, A. L. (2010). Uses and Gratifications of Social media: A Comparison of Facebook and Instant Messaging. Bulletin of Science, Technology \& Society.

[58] Quirk, R., S. Greenbaum, G. Leech \& J. Svartik. (1985). A Grammar Contemporary English Language, Longman, London.

[59] Quirk, R., S. Greenbaum, G. Leech \& J. Svartik. (1985). A Comprehensive Grammar of the English Language, Longman, London.

[60] Radford, A. (2009). An Introdcution to English Sentence Structure. Cambridge University Press.

[61] Radford, A. (1997). Syntactic Theory and the Structure of English. A Minimalist Approach. Cambridge University Press, Cambridge.

[62] Rambe, P. (2011). Exploring the Impacts of Social Networking Sites on Academic Relations in the University. Journal of Information Technology Education.

[63] Rojas, Frank A. (2012). Students' Perspective of the Role of Facebook in their Studies. Florida International University

[64] Schriffin, D. (1994). Approaches to Discourse: Language as Social Interaction. Blackwell Textbook in Linguistics. Wiley.

[65] van Dijk, T. A. (1984). Prejudice in Discourse. Amsterdam: Benjamin

[66] van Dijk, T. A. (1987). Communicating Racism: Ethnic Prejudice in Thought and Talk. Newbury Park, CA: Sage.

[67] van Dijk, T. A. (1988a). News as Discourse, Hillsdale, NJ: Erlbaum

[68] van Dijk, T. A. (1991). Racism and the Press. London: Routledge and Kegan Paul.

[69] van Dijk, T. A. (1993a). Elite Discourse and Racism. Newbury Park, CA: Sage.

[70] van Dijk, T. A. (1993b). Principles of critical discourse analysis. Discourse and Society 4(2), 249-83

[71] van Dijk, T. A. (1996). Discourse, power and access. In R. C. Caldas-Coulthard and M. Coulthard (eds), Texts and Practices: Readings in Critical Discourse Analysis (pp. 84-104). London Routledge and Kegan Paul.

[72] van Dijk, T. A. (1998a). Ideology. A Multidisciplinary Study. London: Sage Publications.

[73] Van Dijk, T.A. (1998b). Opinions and Ideologies in the Press. In Bell, Allan and Peter Garrett (Eds.). Approaches to Media Discourse. Oxford: Blackwell

[74] van Dijk, T.A. (1996). Discourse, Opinions and Ideologies. In Christina Schaffner \& Helen Kelly-Holmes (eds.) Discourse and Ideologies. Clevedon: Multilingual matters Ltd, 1996. 7-37

[75] van Dijk, T.A. (1995). Discourse Analysis as Ideology Analysis. In Christiina Schaffner and Anita L. Wenden (eds.). Language and Peace. Dartmouth: Aldershot. Pp.17-33.

[76] Van Leeuwen, T. (1996). "The Representation of Social Actors". In: C. M. Caldas-Coulthard \& M. Coulthard.

[77] Wodak, Ruth and Meyer, Michael (2008). Critical Discourse Analysis: History, Agenda, Theory, and Methodology.

[78] Wodak, Ruth (2000a). Discourses of Exclusion: a European Comparative Study: Speech at the Opening of the EU Observatorium, 7/8 April, 2000, Hofburg Vienna.

[79] Wodak, R., van Dijk, T. A. (2000). Racism at the Top. Klagenfurt: Drava Verlag.

[80] Wodak, R. \& Ludwig, C.(1999). Challenges in a changing world: Issues in Critical Discourse Analysis, Vienna: Passagenverlag.

[81] Wodak, R. (1997). Gender and Discourse, London: Sage

[82] Wodak, R. (1996). Disorders of Discourse London: Longman

[83] Wodak, Ruth (1996). Orders of Discourse. New York: Addison Wesley Longman. pp. (1-21).

International Journal on Studies in English Language and Literature (IJSELL) Page |30 
[84] Wodak, Ruth (1995). Critical Linguistics and Critical Discourse Analysis. In Jef Verschuren, Jan-Ola Ostman, and Jan Blommaert (eds.). Handbook of Pragmatics- Manual. Amsterdam/Philadelphia: John Benjamins Publishing Company. pp. 204-210.

[85] Wodak, R. (1985). The Interaction Between Judge and Defendant. In T. A. van Dijk Handbook of Discourse Analysis. (ed.), Handbook of Discourse Analysis Vol. 4. Discourse Analysis in Society (pp. 181-91). London: Academic Press

Citation: Pastolero, Nelson P. "Critical Discourse Analysis on Students' Comments on Tate Confessions" International Journal on Studies in English Language and Literature (IJSELL), vol 9, no. 9, 2021, pp. 9-31. doi: https://doi.org/10.20431/2347-3134.0909002.

Copyright: (C) 2021 Authors. This is an open-access article distributed under the terms of the Creative Commons Attribution License, which permits unrestricted use, distribution, and reproduction in any medium, provided the original author and source are credited. 